\title{
Mouse Nerve Growth Factor Prevents Degeneration of Axotomized Basal Forebrain Cholinergic Neurons in the Monkey
}

\author{
Vassilis E. Koliatsos, ${ }^{1,2,5}$ Haring J. W. Nauta, ${ }^{3}$ Richard E. Clatterbuck, ${ }^{5}$ David M. Holtzman, ${ }^{6}$ William C. Mobley, ${ }^{6}$ \\ and Donald L. Price $1,2,4,5$ \\ Departments of ${ }^{P}$ Pathology, ${ }^{2}$ Neurology, ${ }^{3}$ Neurosurgery, and ${ }^{4}$ Neuroscience, and the 5 Neuropathology Laboratory, The \\ Johns Hopkins University School of Medicine, Baltimore, Maryland 21205-2182, and ${ }^{6}$ Department of Neurology, University \\ of California at San Francisco, San Francisco, California 94143
}

NGF, a trophic polypeptide, is necessary for the normal development and survival of certain populations of neurons in the CNS and PNS. In the CNS, cholinergic neurons of the basal forebrain magnocellular complex (BFMC) are prominent targets of NGF. During rat development, NGF increases the activity of ChAT in these neurons. In adult rats with experimental injury of axons in the fimbria-fornix, NGF prevents degenerative changes in axotomized cholinergic BFMC neurons in the medial septal nucleus (MSN). Because the amino acid sequences of NGF and its receptor (NGF-R) are highly conserved across species, we hypothesized that mouse NGF would also prevent degeneration of cholinergic BFMC neurons in nonh.,man primates. Therefore, the pres: ent study was designed to test whether fimbria-fornix lesions result in retrograde degenerative changes in basal forebrain cholinergic neurons in macaques, whether these changes are prevented by mouse NGF, and whether the protective effect of NGF is selective for cholinergic neurons of the basal forebrain. Following unilateral complete transection of the fornix, animals were allowed to survive for 2 weeks, during which time half of the subjects received intraventricular NGF in vehicle and the other half received vehicle alone. In animals receiving vehicle alone, there was a $55 \%$ reduction in the number of ChAT-immunoreactive cell bodies within the MSN ipsilateral to the lesion; loss of immunoreactive somata was more severe in caudal planes of the MSN. Remaining immunoreactive neurons appeared smaller than those in control, unoperated animals. In Nissl stains, there was no apparent loss of basophilic profiles in the MSN, but cells showed reduced size and intensity of basophilia. Treatment with NGF almost completely prevented reductions in the number and size of cholinergic neurons

\footnotetext{
Received Apr. 5, 1990; revised July 20, 1990; accepted July 24, 1990.

The authors thank Drs. Allan Levey and Mark Bothwell, who kindly provided the monoclonal antibodies AB8 (ChAT) and NGFR5 (NGF-R); Drs. Michael D. Applegate, Lary C. Walker, Cheryl A. Kitt, and Linda C. Cork, who had helptul discussions with the authors; Dr. Melih Arici, who performed the ELISA assay for NGF; Mrs. Dawn Spicer and Mr. Lance Rowland, who provided excellent technical assistance; and Mr. Jaan Natkin, who assisted with the cell morphometry. This work was supported by U.S. Public Health Service Grants NIH AG 05146 and NS 20471, The Robert L. and Clara G. Patterson Trust, the American Health Assistance Foundation, and the Metropolitan Life Foundation. D.L.P. is the recipient of Javits Neuroscience Investigator Award NIH NS 10580 and Leadership and Excellence in Alzheimer's Disease (LEAD) Award NIA AG 07914.

Correspondence should be addressed to Vassilis E. Koliatsos, M.D., The Johns Hopkins University School of Medicine, Neuropathology Laboratory, 600 North Wolfe Street, 509 Pathology Building, Baltimore, MD $21205-2181$.

Copyright (C) 1990 Society for Neuroscience 0270-6474/90/123801-13\$03.00/0
}

and had a significant general effect in preventing atrophy in basophilic magnocellular neurons of the MSN, though some basophilic neurons in the MSN did not appear to respond to NGF. Adjacent 7- $\mu \mathrm{m}$-thick sections stained with ChAT and NGF-R immunocytochemistry revealed that these markers are strictly colocalized in individual neurons in the MSN in controls and in both groups of experimental animals. Thus, mouse NGF profoundly influences the process of axotomyinduced retrograde degeneration in cholinergic BFMC neurons in primates. The in vivo effectiveness of mouse NGF on primate BFMC neurons suggests that mouse or human recombinant NGF may be useful in ameliorating the $\mathrm{ACh}$ dependent, age-associated memory impairments that occur in nonhuman primates. Such experiments will prove essential for the design of strategies for use of tropic factors in human diseases associated with degeneration of basal forebrain cholinergic neurons.

In the CNS and PNS, certain populations of neurons are dependent for their normal development and survival on NGF, a 13-kDa peptide (Korsching et al., 1985; Thoenen et al., 1987; Whittemore and Seiger, 1987; Mobley et al., 1989). Projection targets of these neurons express NGF mRNA and protein (Korsching et al., 1985; Shelton and Reichardt, 1986; AyerLeLievre et al., 1988). At target fields, NGF is taken up by highaffinity NGF receptors (NGF-R) on nerve terminals (Greene and Shooter, 1980; Taniuchi et al., 1986; Stach and Perez-Polo, 1987), and the complex of NGF with its receptor is transported rctrogradely to neuronal cell bodies (Seiler and Schwab, 1984; Johnson et al., 1987), where it has a number of actions, including apparent enhancement of cell viability (Hefti et al., 1988). In the CNS, cholinergic neurons of the basal forebrain magnocellular complex (BFMC) are the main targets of NGF. During development, NGF increases levels of ChAT activity in rat BFMC neurons (Gnahn et al., 1983; Hefti et al., 1985; Mobley et al., 1986; Gähwiler et al., 1987; Johnston et al., 1987; Martínez et al., 1987) and the expression of a variety of genes, including those coding for the prion protein and the amyloid precursor protein (Mobley et al., 1988). In adult rats with fimbria-fornix lesions, NGF treatment prevents the axotomy-induced degenerative changes that occur in BFMC cells (Hefti, 1986; Williams et al., 1986; Kromer, 1987; Gage et al., 1988; Rosenberg et al., 1988; Whittemore et al., 1989).

To date, there has been no direct examination of the actions of NGF in nonhuman primates. However, several indirect lines 
of evidence suggest that BFMC neurons of primates are capable of responding to NGF. The amino acid sequence of NGF, including 1 hydrophilic domain around residue 33 (glycine) implicated in the binding of NGF to its receptor, is highly conserved across species (Angeletti and Bradshaw, 1971; Dunbar et al., 1984; Meier et al., 1986). NGF-R, also highly conserved (Johnson et al., 1986), is expressed in BFMC neurons of primates (Hefti et al., 1986; Schatteman et al., 1988). Because of the conservation of NGF and NGF-R, it is likely that mouse NGF can act upon primate neurons that express NGF-R. Consistent with this prediction is the preliminary observation that developing neurons of the human dorsal root ganglia respond to mouse NGF (Caviedes and Rapoport, 1988).

To test the potential for NGF to ameliorate the effects of BFMC cell injury in primates, we used a well-established, simple model: transection of axons of BFMC neurons in the septohippocampal pathway. These axons originate in cholinergic and other neurons of the medial septal nucleus (MSN) and nucleus of the diagonal band of Broca (DBB) and course to hippocampal targets predominantly in the fornix (Swanson and Cowan, 1979), a dorsally coursing discrete bundle that is easily accessible to experimental manipulations (Fig. $1 A$ ). In the rat, following transection of the fornix, neurons of the MSN show reductions in cell size, decrements in cholinergic markers (AChE histochemical activity and ChAT immunoreactivity), and alterations in elements of the neuronal cytoskeleton (Daitz and Powell, 1954; McLardy, 1955; Sofroniew et al., 1983, 1987; Pearson el al., 1984; Gage et al., 1986; Hefti, 1986; Armstrong et al., 1987; Koliatsos et al., 1989a). Eventually, there is evidence of cell loss (Gage et al., 1986; Armstrong et al., 1987; Applegate et al., 1989; Koliatsos et al., 1989a; O'Brien et al., 1990; Tuszynski et al., 1990). The present study demonstrates that similar events occur in macaque monkeys following transection of BFMC axons in the fornix, and that mouse NGF prevents the axotomy-induced degenerative changes induced in these cholinergic BFMC neurons.

Preliminary data from this study have been presented in abstract form (Koliatsos et al., 1989b).

\section{Materials and Methods}

Surgery. Cynomolgus monkeys (Macaca fascicularis; $n=10$; weight, 3-7 kg) were used as subjects in this study. Seven animals were anesthetized with halothane, intubated, and artificially ventilated; 3 animals served as unoperated controls. To facilitate brain relaxation and minimize retraction pressure, mannitol $(20 \%)$ was infused systemically over $30 \mathrm{~min}(2 \mathrm{gm} / \mathrm{kg}$, i.v.) prior to craniotomy; subsequently, mannitol was replaced with normal saline at a continuous, slow intravenous drip throughout surgery. Under sterile conditions, the dura was exposed through a $10-\mathrm{mm}$ trephine hole drilled $10-20 \mathrm{~mm}$ anterior to the interaural line. The sagittal sinus was retracted and the 2 hemispheres separated. The body of the fornix was visualized through a lateral callosotomy 13-14 mm anterior to the interaural line (Szabo and Cowan, 1984) approximately $5 \mathrm{~mm}$ caudal to the MSN; fornical fibers on the right half of the body of the fornix were transected at the coronal plane with an arachnoid knife. The lesion was completed with a coronal $(\mathrm{T}$ like) extension of the callosomy to the midline. Immediately following the lesion, a 12-mm ventricular access device (Model 44100, Connell Neurosurgical, Exton, PA), appropriately modified for the monkey brain, was introduced transcortically or via the callosotomy window into the lateral ventricle and secured in place with sutures passing through the pericranium (Fig. 1B,C). To confirm stable placement of the ventricular access device within the ventricle, metrizamide $(0.5 \mathrm{ml})$ was infused into the reservoir, and a digital ventriculogram was obtained. All animals recovered without complications.

NGF administration. Mouse NGF was prepared by ion-exchange chromatography and characterized by gel electrophoresis and by a chick dorsal root ganglion bioassay as described previously (Mobley et al.,
1986). Prior to use, NGF was passed through a $0.2-\mu \mathrm{m}$ filter (Uniflo, Schleicher and Schuell, Keene, NH) and stored at $200 \mu \mathrm{g} / \mathrm{ml}$ in $0.2 \%$ acetic acid at $-70^{\circ} \mathrm{C}$. NGF was lyophilized and resuspended in acidified cerebrospinal fluid (CSF; see below) immediately prior to the intraventricular injection.

Following surgery, NGF dissolved in vehicle $(n=3)$, or vehicle alone $(n=3)$, was injected immediately and then every second day under aseptic conditions into the Silastic reservoir of the ventricular access device (625 $\mu \mathrm{g}$ per injection for a total of 8 injections, resulting in a total dose of $5 \mathrm{mg}$ ). Vehicle consisted of roughly $300 \mu \mathrm{l}$ acetic acidacidified artificial CSF, pH 7.0 [in mM: $\mathrm{NaCl}, 122.6 ; \mathrm{NaHCO}_{3}, 26.2$; $\mathrm{KCl}, 5.4 ; \mathrm{MgSO}_{4}, 2.0 ; \mathrm{NaH}_{2} \mathrm{PO}_{4}, 1.2 ; \mathrm{CaCl}_{2}, 2.0$; glucose, 10.0 (Cole et al., 1989)]. Following delivery of NGF, the ventricular access device was further washed with an additional $300 \mu \mathrm{l}$ of artificial CSF in order to insure that NGF was not retained within the components of the ventricular access device. Cytochrome $\mathrm{C}$ was not used as a control drug, because, in a preliminary case, we found that it caused reactive astrocytosis, primarily in circumventricular brain regions. In all animals, small samples of CSF were withdrawn from the reservoir before each NGF application, and levels of NGF in the CSF were determined in a 2-site enzyme-linked immunoabsorbent assay (ELISA) performed as described (Weskamp and Otten, 1987; Mobley et al., 1989).

Histology and immunocytochemistry. Two weeks after the onset of treatment, monkeys were perfused via the aorta with 2-3 liters PBS $(\mathrm{pH}, 7.4)$, followed by roughly 6 liters $3 \%$ freshly depolymerized paraformaldehyde (duration of perfusion-fixation, $25 \mathrm{~min}$ ). Unoperated animals were prepared in the same way. Brains were blocked stereotaxically, and blocks were rinsed and cryoprotected in $20 \%$ sucrose in $0.1 \mathrm{M}$ phosphate buffer $(\mathrm{pH}, 7.4)$ for at least $24 \mathrm{hr}$. Sections through the septal region were cut at the transverse plane on a cryostat and processed in series for Cresyl violet $(40 \mu \mathrm{m})$; Cresyl violet $(10 \mu \mathrm{m})$; ChAT immunocytochemistry $(40 \mu \mathrm{m})$, using the monoclonal antibody AB8 (Levey et al., 1983) according to published protocols (Koliatsos et al., 1989a); NGF-R immunocytochemistry $(40 \mu \mathrm{m})$, using the monoclonal antibody NGFR5 (Marano et al., 1987); and immunocytochemistry for phosphorylated neurofilaments $(40 \mu \mathrm{m})$, using antibodies 6-17 and 7-05 (Koliatsos et al., 1989a). For NGF-R immunocytochemistry, sections were pretreated in $0.4 \%$ Triton X-100 (TX) in Tris-buffered saline (TBS) for $30 \mathrm{~min}$, then in $5 \%$ normal goat serum in TBS including $0.1 \% \mathrm{TX}$ for $1 \mathrm{hr}$. Sections were then incubated sequentially in the primary antibody diluted 1:80,000 (48 hr) and, after 3 rinses (10 min cach) in TBS, in affinity-purified goat anti-mouse $\operatorname{IgG}(1: 100,1 \mathrm{hr})$. Both antibodies were diluted in TBS including $2 \%$ normal goat serum and $0.1 \%$ TX. Sections were rinsed again and placed in monoclonal mouse peroxidaseantiperoxidase diluted 1:200 in the same diluent as the primary and secondary antibody but without TX. All previous incubations and rinses were performed at $4^{\circ} \mathrm{C}$. After the peroxidase-antiperoxidase step, sections were rinsed again and taken for a standard diaminobenzidine chromagen reaction. To characterize the lesion, sections through the fornix were stained with Cresyl violet and with immunocytochemistry for the phosphorylated neurofilament epitope 6-17. Sections through the hippocampus were processed for ChAT immunocytochemistry or AChE histochemistry using a silver intensification of the Tsuji reaction (Tsuji, 1974).

In sclected animals from all 3 groups, pairs of adjacent $7-\mu \mathrm{m}$-thick sections (200 $\mu \mathrm{m}$ apart; on average, 10 pairs per monkey brain) were processed for NGF-R and ChAT immunocytochemistry on slides. Procedures were essentially the same as with the floating sections, with the following exceptions: incubations were done at room temperature, concentrations of primary antibodies were 1:25 for ChAT and 1:1000 for NGF-R, the concentration of linking antibody (goat anti-mouse) was 1 : 20 , and the concentration of mouse peroxidase-antiperoxidase was 1 : 100. The purpose of this dual immunocytochemical protocol was to examine the degree of concomitant expression of ChAT and NGF-R immunoreactivity in single neurons of the MSN under normal conditions and following axotomy with or without NGF treatment.

Morphometry and statistics. Numbers and sizes of ChAT-immunoreactive or Nissl-stained perikarya of the MSN on lesioned and unlesioned sides, as well as from 3 normal, unlesioned controls, were quantified using a computerized image analysis system (Loats Associates, Westminster, MD). A total of 4 pairs of sections, $300 \mu \mathrm{m}$ apart and representing standard transverse planes (Fig. 2), were analyzed from each case. Adjacent Nissl- $(10-\mu \mathrm{m})$ and ChAT-stained $(40-\mu \mathrm{m})$ sections were used for quantitation. In ChAT preparations, all obvious perikaryal cholinergic profiles within the MSN were selected for analysis. In Nisslstained sections, a rectangular frame was placed over the MSN on both sides with its longitudinal axis corresponding to the midline. The same 

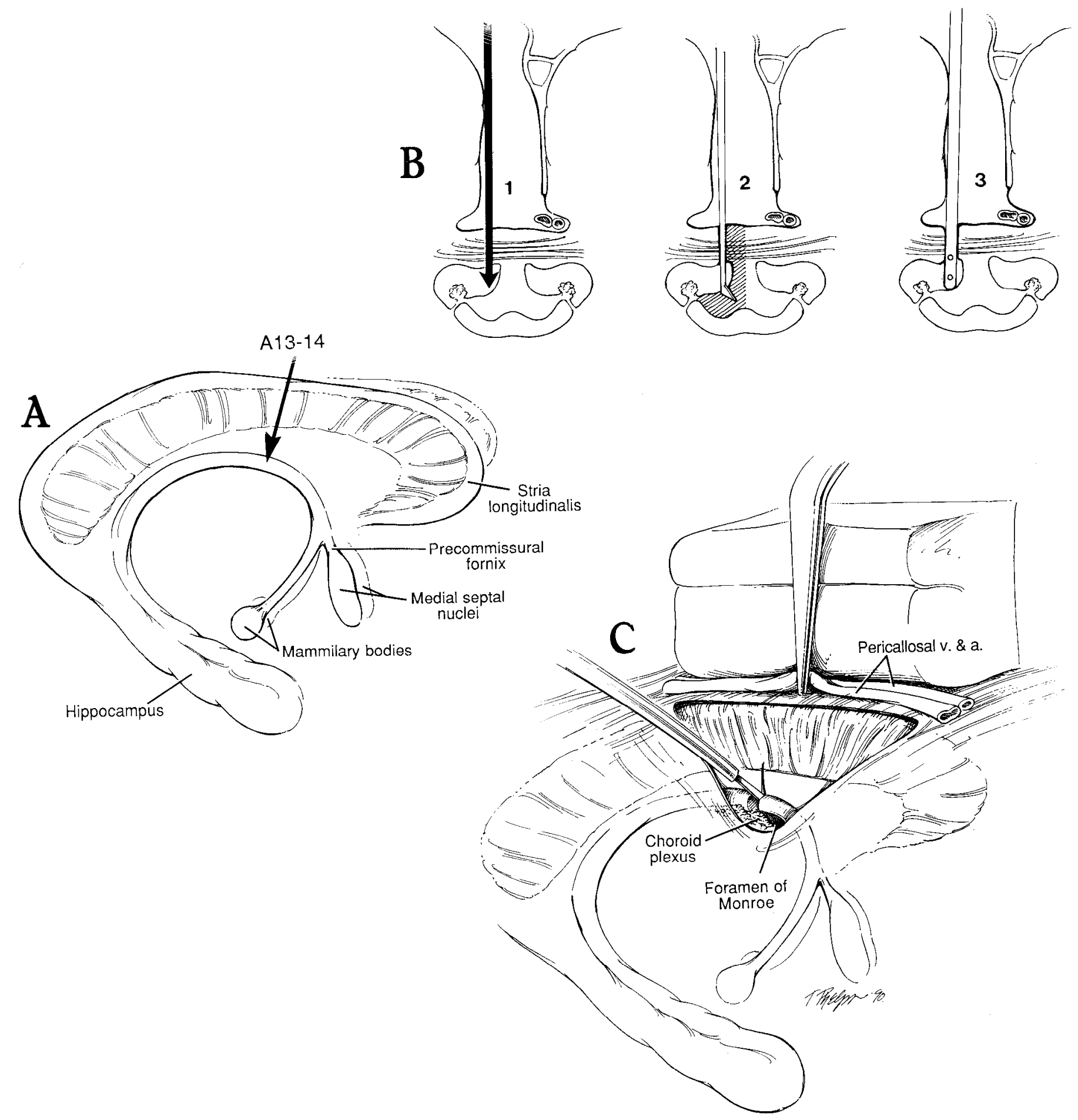

Figure 1. Diagram of location and type of lesion and implantation of infusion device. $A$, The anatomy of the septohippocampal system and fornix in the monkey is depicted. The lesion was placed in the body of the fornix (arrow). The number at the top of the arrow represents the distance (in $\mathrm{mm}$ ) from the interaural line. $B$, A lateral callosotomy permits access to the right half of the body of the fornix (panel 1 ), which is subsequently transected at the coronal plane together with perforating fornical branches in the corpus callosum (panel 2, shaded area). Subsequently, the cannula of the vehicular access device is implanted in the ipsilateral lateral ventricle through the window of the callosotomy (panel 3). C, Three-dimensional rendering of the callosotomy-fornical lesion; see text and B, panels 1 and 2.

area (in $\mu \mathrm{m}^{2}$ ), representing half of the rectangle and covering most of the nucleus, was scanned bilaterally (Fig. $2 c$ ). This strategy was chosen to eliminate inconsistencies in sampling neurons in lateral sectors of the MSN, which can be easily confused with cells of the lateral septum in conditions associated with atrophy of cells in the MSN. In all cases, neurons were outlined, and the area was calculated using an automatic edge-detection program. Particular effort was made to eliminate ChATimmunoreactive swollen fiber fragments (present only in the caudal MSN in lesioned animals) from analysis.

For statistical analysis, the numbers of neurons ipsilateral to the lesion were expressed as percentages of numbers of nerve cells on the unlesioned side. Counts were corrected for differences in cell size by applying 

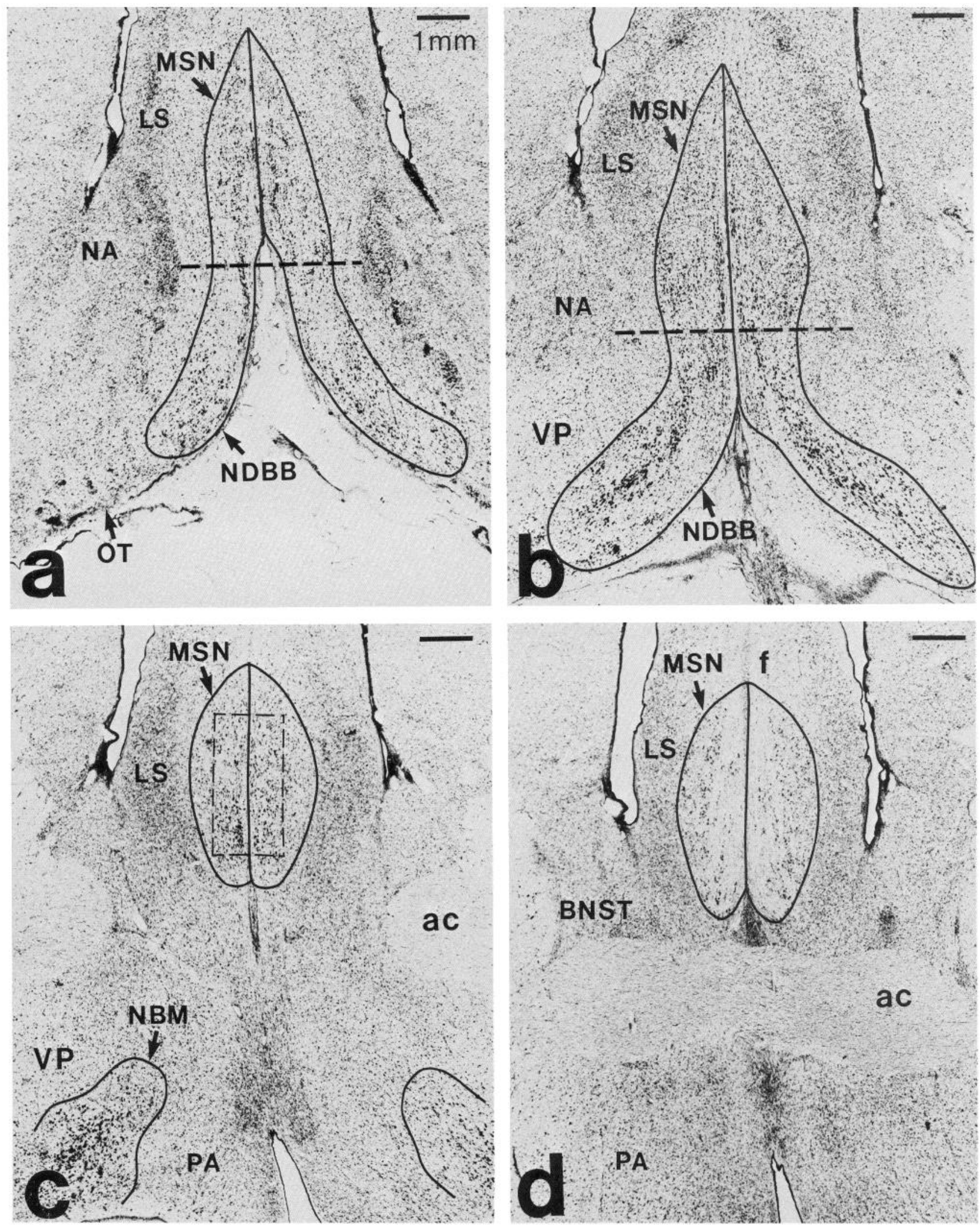

Figure 2. Standard coronal planes through MSN, where quantitative cell data were obtained. In all planes, a solid line indicates the medial plane and outlines various components of the BFMC. Scale bars, $1 \mathrm{~mm}, a-d$. $a c$, anterior commissure; $B N S T$, bed nucleus of stria terminalis; $f$, fornix (precommissural); $L S$, lateral septum; $M S N$, medial septal nucleus; $N A$, nucleus accumbens; $N B M$, nucleus basalis of Meynert; $N D B B$, nucleus of DBB; $O T$, olfactory tubercle; $P A$, preoptic hypothalamic area; $V P$, ventral pallidum. $a$, In this rostralmost plane, the MSN is continuous with the nucleus of the DBB. The horizontal dashed line, which passes through the border of the middle with the lower third of the nucleus accumbens, demarcates the MSN from the nucleus of the DBB. $b$. In this plane, the MSN is readily separated from the nucleus of the DBB (horizontal dashed line). $c$, In this plane, immediately rostral to the commissural decussation, the MSN is entirely separate from the nucleus of the DBB. The rectangle outlined with the dashed line denotes the area quantitated in Nissl sections (same metbod was followed for all planes, $a-d$ ). $d$, Plane midlevel through the decussation of the anterior commissure, representing the caudalmost plane at which quantitative MSN data were collected. 

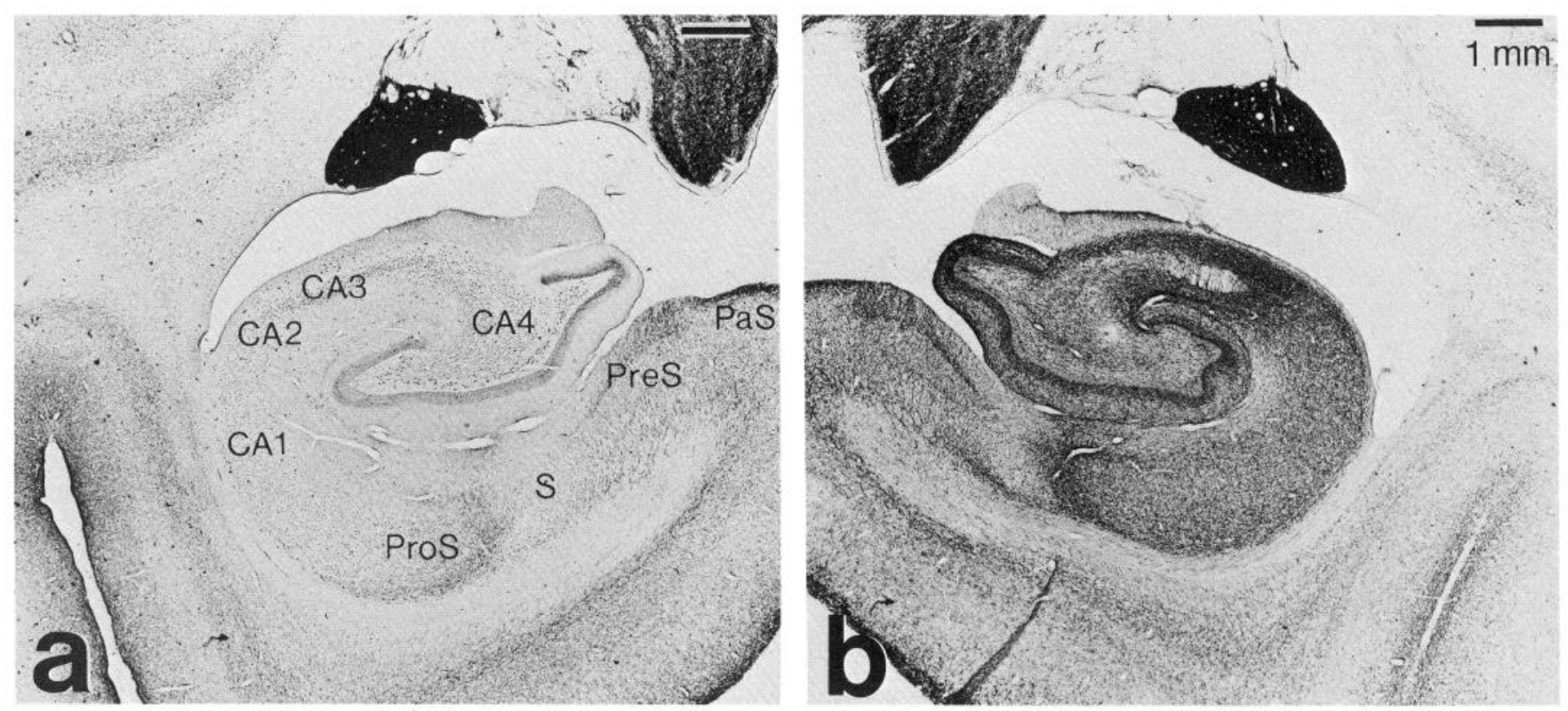

Figure 3. Efficacy of lesion. A profound reduction in AChE staining in the hippocampus ipsilateral to the lesion (a) as compared to the control side $(b)$ is shown. The comparison confirms the cholinergic deafferentation of the hippocampus and, accordingly, the completeness of the transection of cholinergic hippocampopetal axons originating in the MSN and nucleus of the DBB. Some persistence of AChE staining in the dentate granule cell layer represents perikaryal reaction. AChE-positive terminal axons of the BFMC are depleted in the molecular and polymorph layers. Moderate AChE histochemical staining in the prosubiculum is believed to derive from cholinergic innervation of the hippocampus via a ventral BFMC efferent pathway (see text). Scale bars, $1 \mathrm{~mm}, a$ and $b . C A 1-C A 4$, Lorente de No's fields of Ammon's horn; Pas, parasubiculum; PreS, presubiculum; ProS, prosubiculum; $S$, subiculum.

Abercrombie's adjustment for split-cell error (Abercrombie, 1946). This correction was chosen after considering several more recent stereological methods that are more appropriately applied to less complex systems (Gundersen et al., 1988a,b). Mean neuronal area was calculated independently and compared to neuronal area at the corresponding level in control, unlesioned animals. For neuronal number, a repeated-measured analysis of variance (ANOVA; BMDP $2 \mathrm{~V}$ program) was applied with surgical procedure (lesion/vehicle or lesion/NGF) as the main factor and level of section as the repeated measure. Duncan's multiple range test was used for post hoc analysis of group differences.

To calculate the percentage of dual-labeled (ChAT and NGF-R) profiles in the MSN in representative cases of vehicle- and NGF-treated animals and controls, initial maps of ChAT- and NGF-R-immunoreactive profiles of the MSN in adjacent sections were generated with the aid of a neuroanatomical mapping system (software provided by Dr. Mark E. Molliver, The Johns Hopkins University School of Medicine); 5 (7- $\mu \mathrm{m}$-thick) pairs of sections were used per animal. Subsequently, mapped ChAT-immunostained sections were superimposed on corresponding adjacent sections stained for NGF-R by overlaying the respective glass slides and carefully matching outlines of sections under the microscope. Sections were studied under $20 \times$ magnification. Using visual clues provided by vessels and spatial arrangement of cell groups, dual-labeled cells were identified and marked on maps of cholinergic and NGF-R-containing neurons generated from the same sections. Dual-labeled neurons were expressed as percentages of the total number of ChAT- and NGF-R-immunoreactive MSN neurons from all 5 pairs of sections analyzed per animal.

\section{Results}

\section{Evaluation of NGF treatment}

In CSF samples collected from NGF-treated animals throughout the period of treatment, NGF was detected at CSF concentrations ranging from 2 to $150 \mu \mathrm{g} / \mathrm{ml}$. In pretreatment samples, the concentration of NGF was below level of detectability by the assay $(100 \mathrm{ng} / \mathrm{ml})$. Samples taken at the end of the treatment period tended to have higher concentrations of NGF. NGF concentration was roughly proportional to the length of treat- ment. Because the ventricular access devices were cleared with CSF at the end of each individual treatment, the upward trend in NGF concentration suggested that NGF levels within the ventricular system increased over time, though the rate and degree of CSF clearance might have been variable.

\section{Efficacy of the lesion}

In all monkeys, there was a profound reduction in levels of AChE histochemical activity and ChAT immunoreactivity in all hippocampal sectors ipsilateral to the lesion throughout the anteroposterior extent of the hippocampal formation (Fig. 3). The prosubiculum showed moderate levels of AChE and ChAT, but, as reported elsewhere (Kitt et al., 1987), this region is innervated, besides the fornix, by a ventral pathway originating in the nucleus basalis and coursing in the ansa peduncularis; this pathway was not damaged by our manipulations. Our immunocytochemical and histochemical preparations of the hippocampus confirmed the efficacy of the transections, and tissues from all these subjects were taken for quantitative analysis of retrograde changes in neurons of the MSN.

\section{Retrograde changes in the MSN}

The septohippocampal system is topographically organized along both the mediolateral and the rostrocaudal axes, with MSN neurons utilizing the fornix exclusively for their hippocampal projections, whereas neurons in the nucleus of the DBB partially project through ventral routes (Swanson, 1976; Kitt et al., 1987; Koliatsos et al., 1988). Therefore, following lesions of the fornix, we focused on retrograde changes in the MSN and effects of NGF on these cholinergic neurons of the BFMC.

In monkeys treated with vehicle, numbers of ChAT- and NGF-R-immunostained cells ipsilateral to the lesion were re- 

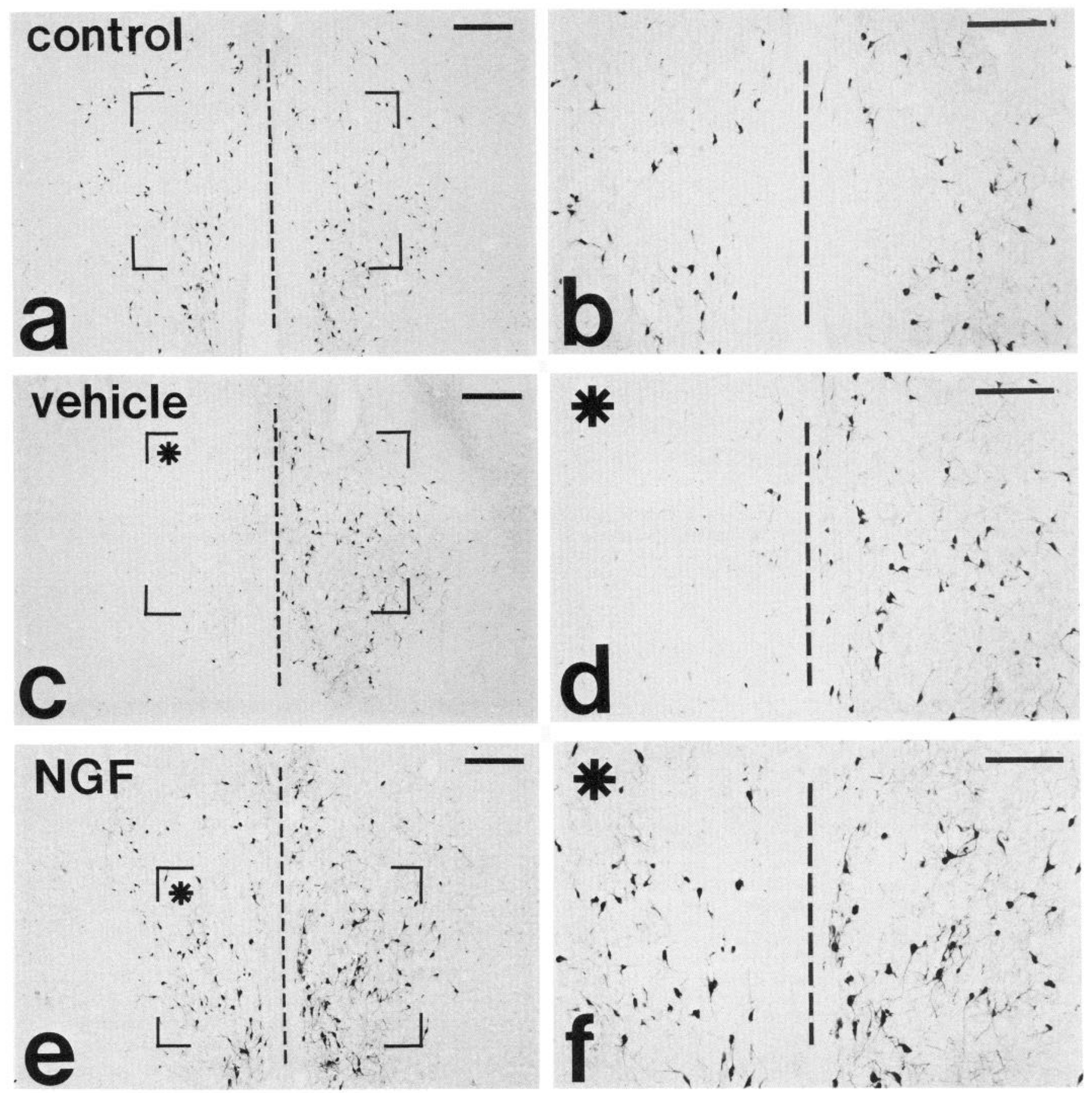

Figure 4. ChAT-immunostained preparations through MSN of unoperated controls $(a, b)$ and of vehicle- $(c, d)$ and NGF-treated $(e, f)$ animals with lesions. Sections have been taken through plane $c$ of Figure 2, which, together with plane d (Fig. 2), show the most profound changes following axotomy and treatment with NGF. $b, d$, and $f$ represent magnifications of the framed areas in $a, c$, and $e$, respectively. In $a$ and $b$, approximately equal numbers of cholinergic neurons are shown on each side. In $c$ and $d$, transection of the fornix (left-hand side) results in a reduction in number and sizes of ChAT-immunoreactive cell bodies. In $e$ and $f, 2$-week treatment with NGF restores the number and sizes of ChAT-immunoreactive cell bodies on the lesioned side; note that cholinergic somata on the lesioned side and especially on the unlesioned side are hypertrophic when compared with control neurons $(b)$. Scale bars: $a, c, e, 300 \mu \mathrm{m} ; b, d, f, 200 \mu \mathrm{m}$. Vertical dashed line indicates the medial plane. Asterisks indicate lesioned side.

duced to roughly $55 \%$ of neurons in the contralateral MSN. Remaining immunoreactive neurons were, on average, smaller than cholinergic MSN neurons from control animals (Figs. 4, 6). In Nissl stains, MSN neurons on the lesioned side showed reduced basophilia and a $10 \%$ reduction in size (Figs. 5, 7). All of these abnormalities were more severe in caudal planes of the
MSN. Based on Nissl stains, there was no apparent loss of neurons on the lesioned side. In fact, morphometric analysis showed a statistically insignificant trend towards increased numbers of neurons. Because the calculated increase in basophilic profiles on the lesioned side $(\sim 10 \%)$ was equal to the average cell shrinkage on the same side, this unexpected difference was 

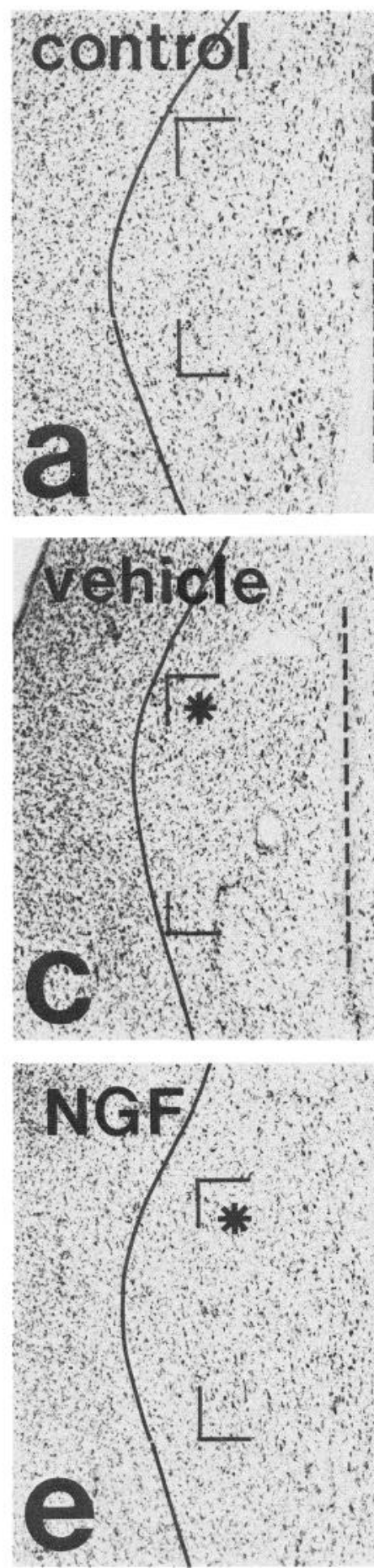
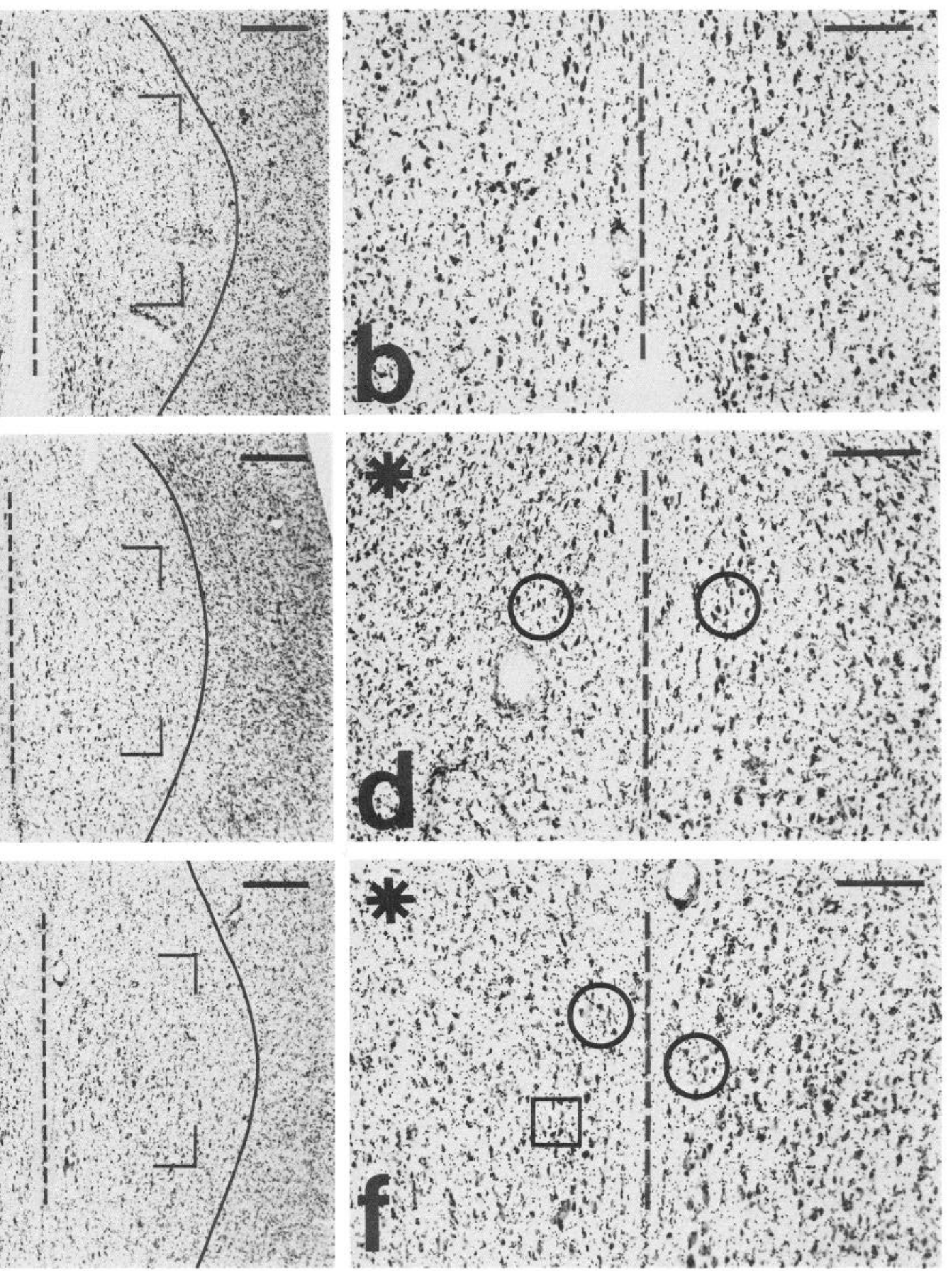

Figure 5. Nissl stains through MSN of unoperated controls $(a, b)$ and of vehicle- $(c, d)$ and NGF-treated $(e, f)$ animals. $b, d$, and $f$ represent magnifications of the framed areas in $a$, $c$, and $e$, respectively. In $a, c$, and $e$, the MSN is separated from the lateral septum by a continuous line. All 3 sections depicted are $40 \mu \mathrm{m}$ thick and adjacent to ChAT-stained sections illustrated in Figure 4 . In $a$ and $b$, normal shapes and sizes of MSN magnocellular neurons are depicted on both sides. In $c$ and $d$, transection of the fornix in the left hemisphere results in shrinkage of basophilic profiles ipsilateral to the lesion [compare circled group of cells in $d$, left, with circled group of cells on the contralateral side (right)]. In $e$ and $f$, treatment with NGF restores the size and shape of certain groups of MSN neurons on the lesioned side $(f$, left, circled; compare with $f$, right, circled), but has no effect on other groups of MSN neurons ( $f$, left, outlined with a square; compare with circled cells on same side). For more details of this dual response, see text and Figure 8. Scale bars: $a, c, e, 300 \mu \mathrm{m} ; b, d, f, 200 \mu \mathrm{m}$.

considered to be caused by reduction in the total area of the MSN on the lesioned side. Some magnocellular MSN neurons contralateral to the lesion also showed evidence of mild atrophy.

In monkeys treated with NGF, there was a dramatic amelio- ration of the retrograde changes described above. No significant reductions were noted in the number of ChAT- and NGF-Rimmunoreactive perikarya on the side of the axotomy. These cells had a normal shape, and their size was, on average, $30 \%$ 
A
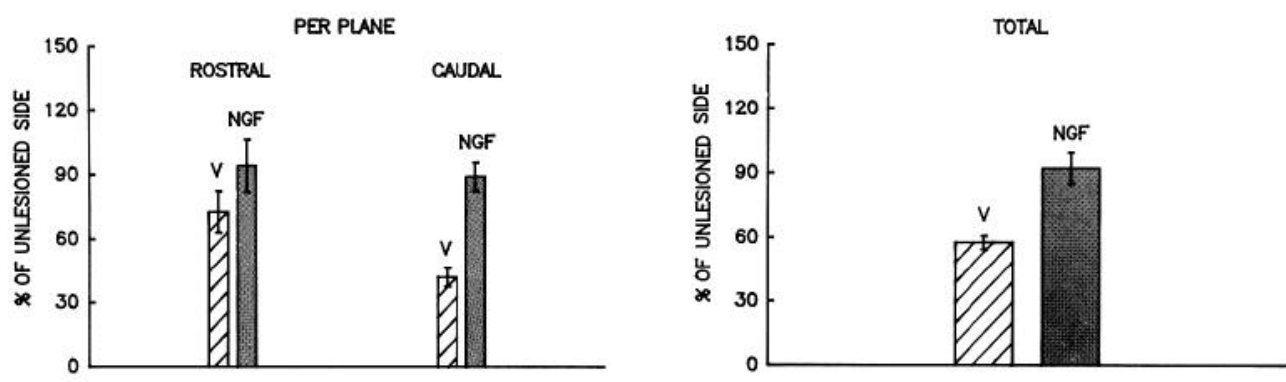

analyzed, the difference was statistically significant by ANOVA $(p=0.0124)$. When the size of the total number of ChAT-immunoreactive neurons was analyzed by ANOVA $(B)$, the size of ChAT-positive cells in the control and vehicle- and NGF-treated groups differed significantly $(p=0.0209)$, but no significant stepwise differences could be detected by Duncan's multiple range test. Per-plane analysis indicated that cholinergic MSN cells in the NGFtreated group were significantly larger than cells in the vehicle-treated group, both rostrally ( $p=0.01843)$ and caudally $(p=0.03554)$, with Duncan's post hoc analysis. $C$, control; $V$, vehicletreated; NGF, NGF-treated. Vertical bars on columns indicate SEM.

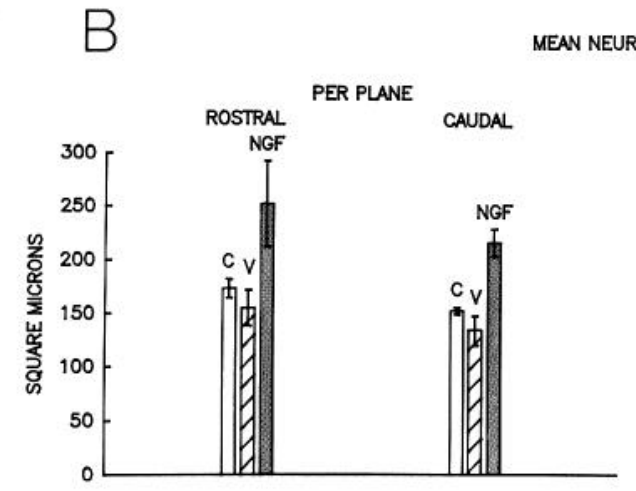

side: one subpopulation, apparently responsive to NGF, exhibited normal size and shape; the other subpopulation showed reduced size and basophilia and altered shape (Figs. $5 f, 8$ ). The effect of NGF was generally more pronounced in caudal than in rostral MSN levels, perhaps related to the proximity of the
Figure 7. Number of basophilic profiles on side ipsilateral to lesion is expressed as percentage of contralateral (unlesioned) side for vehicle- and NGFtreated groups, per plane of section and overall $(A)$. When all quantitated cells on the lesioned side of the vehicle- and NGF-treated groups were analyzed, no statistical significance was shown. When the size of basophilic profiles in these sections was considered per plane $(B$, $l e f t$ ), the only significant difference was present between cells in the caudal plane of the control and vehicle-treated subjects $(p=0.02275$, Duncan's multiple range test). When all levels are grouped and considered with ANOVA ( $B$, right), the size of basophilic profiles in the control and vehicle- and NGF-treated groups differed significantly ( $p=$ 0.0475 ), but no significant stepwise differences could be detected by Duncan's multiple range test. $C$, control; $V$, vehicle-treated; $N G F$, NGF-treated. Vertical bars on columns indicate SEM.

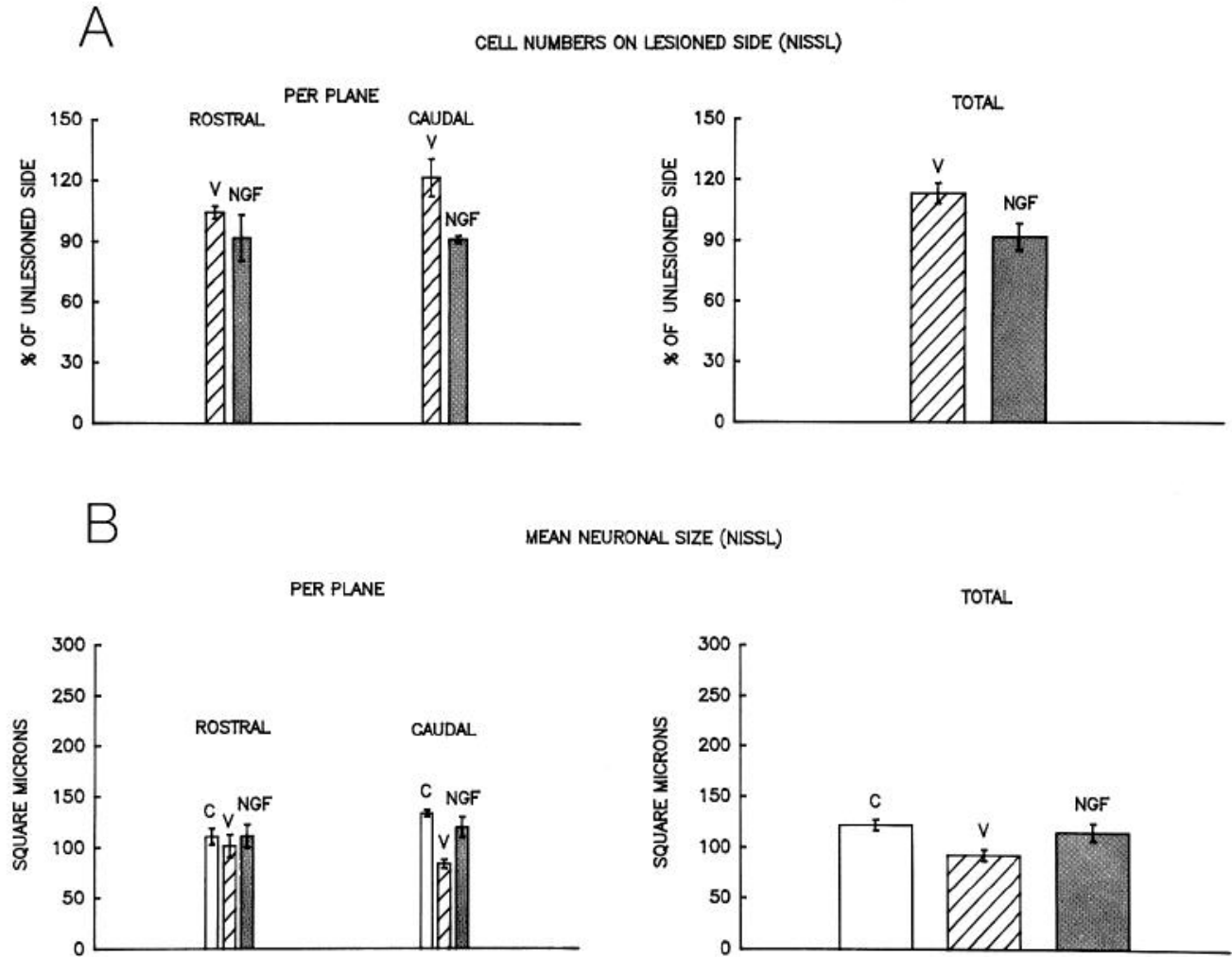




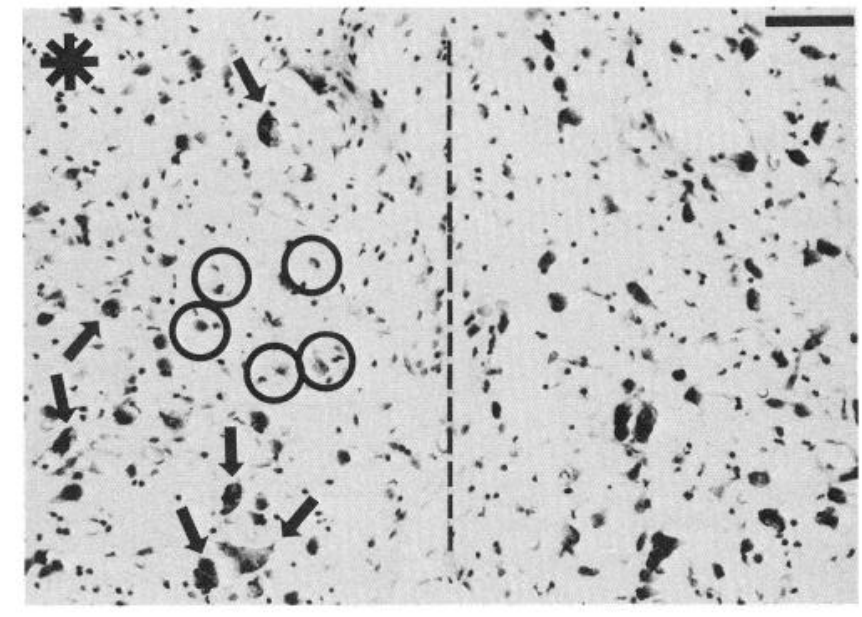

Figure 8. Nissl-stained section (10 $\mu \mathrm{m}$ thick), taken from plane $\mathrm{c}$ of Figure 2 in lesioned/NGF-treated monkey. Asterisk indicates lesioned side. Although all stained perikarya on the unlesioned side appear healthy, only a subpopulation of cells on the side of the lesion have normal shape and size (arrows). A number of cells on the lesioned side are atrophic (circles). Scale bar, $60 \mu \mathrm{m}$.

site of infusion and a higher local concentration of NGF. Remarkable hypertrophy of cholinergic MSN neurons was noted contralateral to the lesion. On the contralateral side, ChATpositive cells were, on average, $55 \%$ larger than MSN cholinergic neurons from control, unoperated animals (Fig. $4 b, f$ ), whereas basophilic profiles on the same side did not show any difference when compared to Nissl-stained profiles in control animals (Fig. $5 b, d, f)$.

The study of adjacent $7-\mu \mathrm{m}$-thick sections stained for ChAT or NGF-R indicated that $95 \%$ of the ChAT-immunoreactive cell bodies in the MSN of control, lesioned/untreated, and lesioned/NGF-treated animals also expressed NGF-R immunoreactivity. There were no NGF-R-immunoreactive cells outside the population of the cholinergic MSN neurons in any of the groups of animals, either on the lesioned side or on the side contralateral to the lesion (Fig. 9).

Sections stained with antibodies for phosphorylated neurofilament epitopes did not show any aberrant (perikaryal) immunoreactivity in the MSN or nucleus of the DBB of any of the control or lesioned/vehicle-treated animals. However, both antibodies 6-17 and 7-05 stained a few magnocellular neurons, located mostly in rostral planes of the MSN in lesioned/NGFtreated animals (Fig. 10).

\section{Discussion}

Our results indicate that mouse NGF has significant biological effects on primate CNS neurons in vivo and can effectively prevent the progressive degenerative changes that occur in BFMC cholinergic neurons following transection of their axons in the fornix. The significance of the NGF effect on primate neurons is 3-fold: heterologous (mouse) NGF is effective on BFMC neurons in primates, the same patterns of NGF-mediated trophic influences appear to exist in species with a much more complex forebrain than the rat, and similar NGF therapy may have benefits for animal and human disorders that show degeneration of cholinergic cells of the BFMC.

The septohippocampal system-a term mainly used in the literature dealing with rodents-is a component of the basal
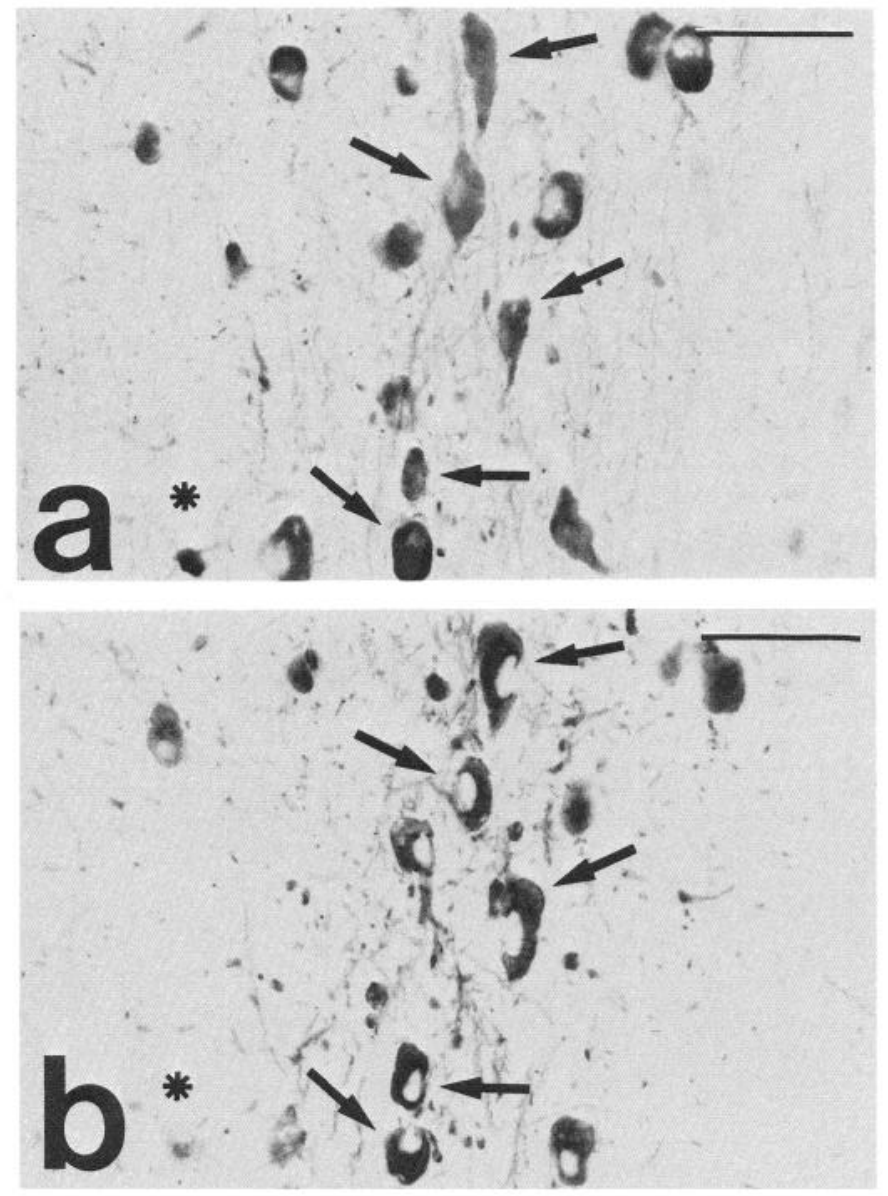

Figure 9. Two adjacent $7-\mu \mathrm{m}$ sections, taken through plane $\mathrm{c}$ of Figure 2 , are illustrated. One section was immunostained with ChAT antibodies $(a)$, and the other was stained with antibodies directed against NGF-R $(b)$. All cholinergic perikarya $(a)$ are also immunoreactive for NGF-R ( $b$; examples are indicated by arrows). Note that only cholinergic cells contain the receptor. Asterisks indicate vessels. Scale bar, $60 \mu \mathrm{m}$.

forebrain-telencephalic projection that originates predominantly from neurons in the MSN and projects primarily via the fornix to hippocampus (Swanson et al., 1987). In the monkey, the system is organized in a similar fashion: axons arise from neurons of the BFMC, situated mostly in the MSN and nucleus of DBB, and project via the fornix and the fimbria to hippocampal targets (Fig. 1A). Approximately $30 \%$ of these neurons are cholinergic, whereas the majority of other cells presumably contain GABA (Koliatsos et al., 1988). In the rat, BFMC axons can reach the hippocampus by routes outside the fimbria-fornix, including the dorsal fornix (Wyss et al., 1980), the cingulate bundle/supracallosal striae (Swanson and Cowan, 1979; Milner et al., 1983), and a less well-defined ventral pathway, containing roughly $10 \%$ of septohippocampal axons (Gage et al., 1984; Milner and Amaral, 1984). In primates, as in rats, there is a ventral pathway, but the majority of these fibers originate in the nucleus basalis and nucleus of the DBB, rather than the MSN (Kitt et al., 1987; Koliatsos et al., 1988). Dorsal pathways outside the fornix do not contribute significantly to the cholinergic innervation of hippocampus in the monkey (Rosene and Van Hoesen, 1987); the monkey does not have a distinct dorsal fornix (Rosene and Van Hoesen, 1977), and it is unlikely that the supracallosal striae, sometimes termed the dorsal fornix 

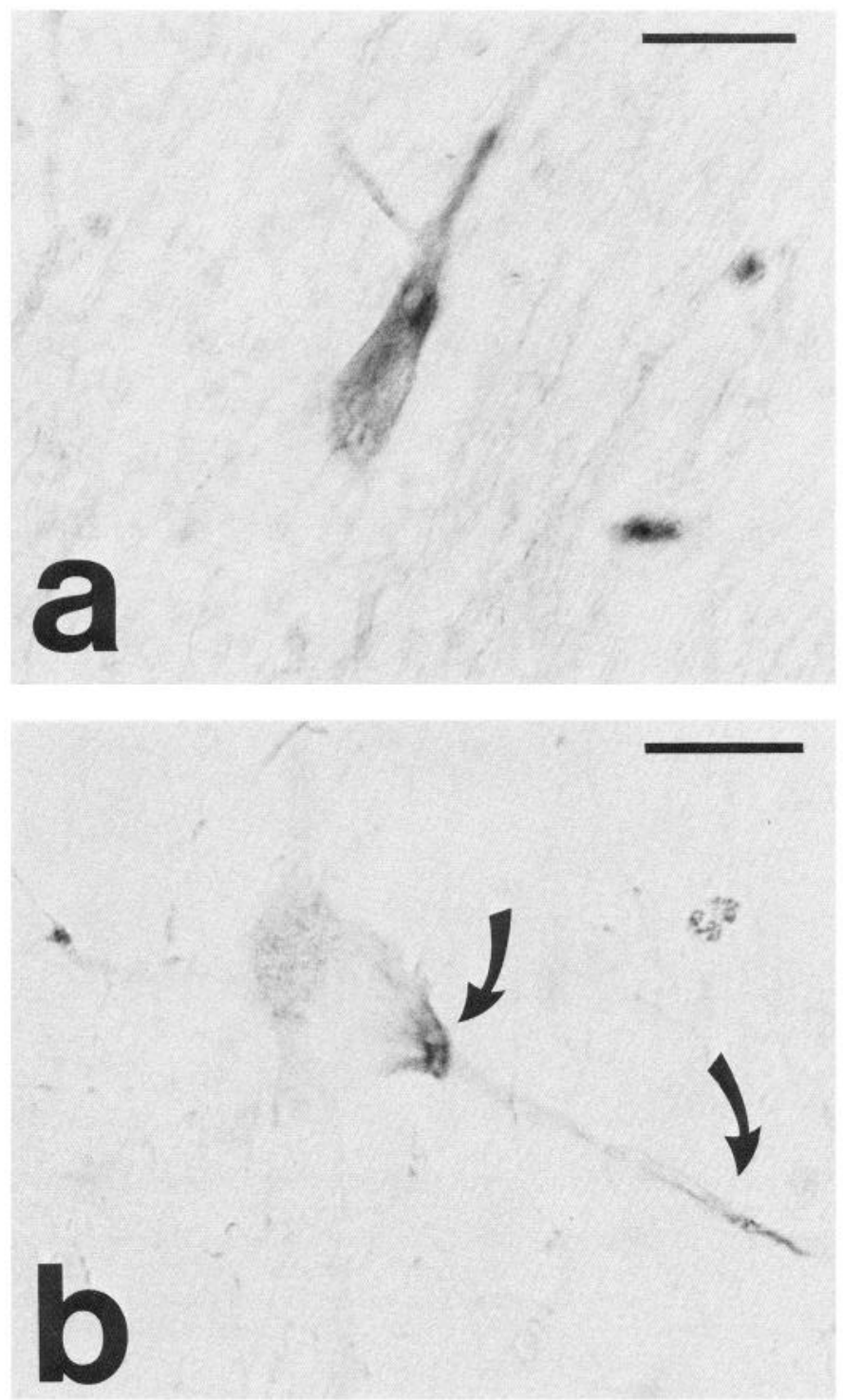

Figure 10. In lesioned/NGF-treated animals, some MSN perikarya contain phosphorylated neurofilaments. Both perikarya depicted in this illustration belong to the anterior MSN. One MSN neuron is stained with antibody 6-17 $(a)$, and the other MSN cell reacts with the neurofilament antibody 7-05 $(b)$. In $b$, note intense immunoreactivity in a dendrite and perikaryodendritic junction (arrows). Scale bar, $20 \mu \mathrm{m}$.

(McLardy, 1955; Poletti and Creswell, 1977), contain significant numbers of efferent and afferent hippocampal fibers (Rosene and Van Hoesen, 1987). The only other dorsal contribution to cholinergic innervation of the hippocampus is made by the callosal perforating fibers (Rosene and Van Hoesen, 1987). Our lesion transected both the fornix and the overlying corpus callosum at the coronal plane. The cingulate bundle and associated fibers were not damaged, as this would result in a large (and unnecessary) midline lesion of the cortex.

The design and time course of our present experiment does not clearly distinguish between 2 possible effects of NGF: prevention of cell death and restoration of the normal phenotype of injured neurons. Indeed, as indicated by our cell counts in Nissl-stained sections, there is no evidence of cell death in the monkey MSN 2 weeks following transection of the fornix. Our studies of the fimbria-fornix axotomy model in the rat indicate that cell death in the MSN becomes prominent between 3 and 4 weeks postaxotomy (Applegate et al., 1989; see also O'Brien et al., 1990; Tuszynski et al., 1990). Similar evidence is provided indirectly by other studies that show significant "retrieval" of ChAT-immunoreactive cell bodies in the MSN after delayed NGF treatment of rats with fimbria-fornix transections (Hagg et al., 1988). Although MSN neurons do not die within the survival time used in our present study, these cells do show altered phenotypes, including reductions in size and transmitterassociated enzymes, as well as alterations in elements of the cytoskeleton, that is, perikaryal phosphorylation of neurofilaments. Similar alterations have been described in rats (Gage et al., 1986; Hefti, 1986; Armstrong et al., 1987; Koliatsos et al., 1989a). Because these abnormalities precede the death of BFMC cells, amelioration by NGF of some of these effects indirectly suggests that NGF can prevent cell death. It should be noted that perikaryal phosphorylated neurofilaments were not prominent in the perikarya of MSN and the nucleus of the DBB in our lesioned/vehicle-treated monkeys. This does not mean that cytoskeletal abnormalities of this type do not occur in axotomized BFMC neurons in primates. As reported in our previous studies in rats (Koliatsos et al., 1989a), the appearance of phosphorylated neurofilaments in perikarya is an early response to axotomy, which, by day 15 following the lesion, may have been considerably attenuated in the monkey. Because the disappearance of phosphorylated neurofilaments in cell bodies following axotomy is very likely associated with cell death (Klosen and van den Bosch de Aguilar, 1987; Koliatsos et al., 1989a), the persistence of this cytoskeletal abnormality in some axotomized MSN neurons in monkeys treated with NGF is an additional indication that NGF delays retrograde degenerative changes that precede cell death. However, the hypothesis that NGF acts to prevent cell death must be tested more directly by NGF treatment of animals with fimbria-fornix lesions for prolonged periods of time (4 weeks), that is, the period within which $50 \%$ of axotomized MSN cells have degenerated (Montero and Hefti, 1988; Applegate et al., 1989).

The magnitude of the effect of NGF on cholinergic neurons of the monkey BFMC was similar to that in rats treated with the same preparation of NGF using ventricular access devices (V. E. Koliatsos, W. C. Mobley, and D. L. Price, unpublished observations). This finding indicates that mouse NGF is potent across species and suggests that NGF domains important for receptor binding and activation (Angeletti and Bradshaw, 1971; Dunbar et al., 1984; Meier et al., 1986) may be conserved in mice and primates. Based on the average size of surviving basophilic profiles, the magnitude of the effect of NGF is smaller than that based on size (and number) of ChAT-immunostained perikarya. This reduced effect is probably due to the fact that Nissl stains reveal 2 subpopulations of basophilic profiles on the lesioned side of NGF-treated animals, one showing signs of responsiveness to NGF, and the other with reduced size and abnormal shape. This discordance was also noted in rats treated with NGF using the same procedures (Koliatsos, Mobley, and Price, unpublished observations) and suggests that noncholinergic neurons of the BFMC may not respond to NGF as do cholinergic neurons. This differential responsiveness to NGF is further supported by our findings on adjacent $7-\mu \mathrm{m}$-thick sections stained with ChAT and NGF-R showing strict colocalization of ChAT and NGF-R immunoreactivity in MSN neurons on both the lesioned and the unlesioned sides in control 
animals and in both experimental groups. Although nerve cells that respond to NGF are bound to express NGF-R, it is conceivable that low levels of NGF-R expression may prevent immunocytochemical detection of all NGF-R-containing neurons. However, in view of the fact that NGF upregulates the expression of NGF-R in cholinergic neurons of the BFMC (Higgins et al., 1989), the correspondence of ChAT and NGF-R immunoreactivity, especially in the NGF-treated group of animals, suggests strongly that only cholinergic MSN neurons bear the NGF-R and respond to NGF.

As discussed above, the majority of noncholinergic cells of the MSN and nucleus of the DBB contain GABA. GABAergic cells comprise at least $30 \%$ of the BFMC cells projecting to the hippocampus (Köhler et al., 1984), and their axons selectively contact inhibitory interneurons in the hippocampus (Freund and Antal, 1988). The magnitude and target specificity of this inhibitory component of the septohippocampal projection suggest that GABAergic septal neurons have a major functional significance in this system (Freund and Antal, 1988). There is disagreement as to whether GABAergic neurons of the BFMC, identified with immunocytochemistry for GABA or glutamic acid decarboxylase, have NGF-R and respond to NGF. Although Dreyfus and co-workers (Dreyfus et al., 1989) have indicated that these nerve cells bear the NGF-R in vitro, in vivo studies did not show septal GABAergic neurons to respond to NGF (Montero and Hefti, 1988). Definitive conclusions on patterns of retrograde degeneration and effects of NGF on GABAergic septal neurons, especially in the monkey, may require in situ hybridization histochemistry for glutamic acid decarboxylase transcripts (Walker et al., 1989).

NGF treatment of animals with lesions of the septohippocampal system may partially restore innervation of deafferented terminal fields (Haroutunian et al., 1986) and may, at least transiently, ameliorate behavioral deficits related to hippocampal denervation (Will and Hefti, 1985). Moreover, NGF has been reported to have effects on age-associated deficits in behaviors dependent on the septohippocampal circuit (Fischer et al., 1987), perhaps by ameliorating degenerative age-related alterations that occur in BFMC neurons. A beneficial effect of NGF on behavior suggests its use in future experiments involving aged, memory-impaired monkeys (Bartus et al., 1979, 1980; Davis, 1985; Presty et al., 1987; Phelps et al., 1989a,b; Bachevalier et al., 1991). This view is further supported by the fact that NGF can upregulate the expression of NGF-R (Higgins et al., 1989), a phenomenon that could serve to enhance further the responsiveness of injured cells to the exogenously supplied trophic factor. If NGF proves effective and nontoxic when chronically administered to nonhuman primates, all of the conditions (Phelps et al., 1989a,b) will have been met for consideration of a carefully designed trial of NGF therapy in individuals with Alzheimer's disease, a disorder in which there is consistent degeneration of BFMC cholinergic neurons (Bowen et al., 1976; Perry et al., 1977, 1982; Davies, 1979; Whitehouse et al., 1982; Arendt et al., 1983; Francis et al., 1985; Price, 1986).

\section{References}

Abercrombie M (1946) Estimation of nuclear population from microtome sections. Anat Rec 94:239-247.

Angeletti RH, Bradshaw RA (197.1) Nerve growth factor from mouse submaxillary gland: amino acid sequence. Proc Natl Acad Sci USA 68:2417-2420.

Applegate MD, Koliatsos VE, Price DL (1989) Extended survival of medial septal cholinergic neurons following lesion of the fimbriafornix. Soc Neurosci Abstr 15:408.

Arendt T, Bigl V, Arendt A, Tennstedt A (1983) Loss of neurons in the nucleus basalis of Meynert in Alzheimer's disease, paralysis agitans, and Korsakoff's disease. Acta Neuropathol (Berl) 61:101-108.

Armstrong DM, Terry RD, DeTeresa RM, Bruce G, Hersh LB, Gage FH (1987) Response of septal cholinergic neurons to axotomy. J Comp Neurol 264:421-436.

Ayer-LeLievre C, Olson L, Ebendal T, Seiger Å, Persson H (1988) Expression of the $\beta$-nerve growth factor gene in hippocampal neurons. Science 240:1339-1341.

Bachevalier J, Landis LS, Walker LC, Brickson M, Mishkin M, Price DL, Cork LC (1991) Widespread behavioral and cognitive deficits in aged monkeys. Neurobiol Aging, in press.

Bartus RT, Dean RL, Fleming DL (1979) Aging in the rhesus monkey: effects on visual discrimination learning and reversal learning. J Gerontol 34:209-219.

Bartus RT, Dean RL, Beer B (1980) Memory deficits in aged Cebus monkeys and facilitation with central cholinomimetics. Neurobiol Aging 1:145-152.

Bowen DM, Smith CB, White P, Davison AN (1976) Neurotransmitter-related enzymes and indices of hypoxia in senile dementia and other abiotrophies. Brain 99:459-496.

Caviedes P, Rapoport SI (1988) Effect of nerve growth factor in the electrical membrane properties of human fetal dorsal root ganglia neurons in culture. Soc Neurosci Abstr 14:825.

Cole AE, Eccles CU, Aryanpur JJ, Fisher RS (1989) Selective depression of $N$-methyl-D-aspartate-mediated responses by dextrorphan in the hippocampal slice in rat. Neuropharmacology 3:249-254.

Daitz HM, Powell TPS (1954) Studies of the connexions of the fornix system. J Neurol Neurosurg Psychiatry 17:75-82.

Davies $P$ (1979) Neurotransmitter-related enzymes in senile dementia of the Alzheimer type. Brain Res 171:319-327.

Davis RT (1985) The effects of aging on the behavior of rhesus monkeys. In: Behavior and pathology of aging in rhesus monkeys, monographs in primatology (Davis RT, Leathers CW, eds), Vol 8, pp 5782. New York: Liss.

Dreyfus CF, Bernd P, Martinez HJ, Rubin SJ, Black IB (1989) GABAergic and cholinergic neurons exhibit high-affinity nerve growth factor binding in rat basal forebrain. Exp Neurol 104:181-185.

Dunbar JC, Tregear GW, Bradshaw RA (1984) Histidine residue modification inhibits binding of murine $\beta$ nerve growth factor to its receptor. J Protein Chem 3:349-354.

Fischer W, Wictorin K, Björklund A, Williams LR, Varon S, Gage FH (1987) Amelioration of cholinergic neuron atrophy and spatial memory impairment in aged rats by nerve growth factor. Nature 329:6568.

Francis PT, Palmer AM, Sims NR, Bowen DM, Davison AN, Esiri MM, Neary D, Snowden JS, Wilcock GK (1985) Neurochemical studies of early-onset Alzheimer's disease. Possible influence on treatment. N Engl J Med 313:7-11.

Freund TF, Antal M (1988) GABA-containing neurons in the septum control inhibitory interneurons in the hippocampus. Nature $36: 170$ 173.

Gage FH, Björklund A, Stenevi U (1984) Cells of origin of the ventral cholinergic septohippocampal pathway undergoing compensatory collateral sprouting following fimbria-fornix transection. Neurosci Lett 44:211-216.

Gage FH, Wictorin K, Fischer W, Williams LR, Varon S, Björklund A (1986) Retrograde cell changes in medial septum and diagonal band following fimbria-fornix transection: quantitative temporal analysis. Neuroscience 19:241-255.

Gage FH, Armstrong DM, Williams LR, Varon S (1988) Morphological response of axotomized septal neurons to nerve growth factor. J Comp Neurol 269:147-155.

Gähwiler BH, Enz A, Hefti F (1987) Nerve growth factor promotes development of the rat septo-hippocampal cholinergic projection in vitro. Neurosci Lett 75:6-10.

Gnahn H, Hefti F, Heumann R, Schwab ME, Thoenen H (1983) NGFmediated increase of choline acetyltransferase (ChAT) in the neonatal rat forebrain: evidence for a physiological role of NGF in the brain? Dev Brain Res 9:45-52.

Greene LA, Shooter EM (1980) The nerve growth factor: biochemistry, synthesis, and mechanism of action. Annu Rev Neurosci 3:353-402. Gundersen HJG, Bendtsen TF, Korbo L, Marcussen N, Moller A, Niel- 
sen K, Nyengaard JR, Pakkenherg B, Sorensen FB, Vesterby A, West MJ (1988d) Some new, simple and efficient stereological methods and their use in pathological research and diagnosis. APMIS 96:379394.

Gundersen HJG, Bagger P, Bendtsen TF, Evans SM, Korbo L, Marcussen N, Moller A, Nielsen K, Nyengaard JR, Pakkenberg B, Sorensen FB, Vesterby A, West MJ (1988b) The new stereological tools: disector, fractionator, nucleator and point sampled intercepts and their use in pathological research and diagnosis. APMIS 96:857881 .

Hagg, T, Manthorpe M, Vahlsing HL, Varon S (1988) Delayed treatment with nerve growth factor reverses the apparent loss of cholinergic neurons after acute brain damage. Exp Neurol 101:303-312.

Haroutunian V, Kanof PD, Davis KL (1986) Partial reversal of lesioninduced deficits in cortical cholinergic markers by nerve growth factor. Brain Res 396:397-399.

Hefti F (1986) Nerve growth factor promotes survival of septal cholinergic neurons after fimbrial transections. J Neurosci 6:2155-2162.

Hefti F, Hartikka J, Eckenstein F, Gnahn H, Heumann R, Schwab M (1985) Nerve growth factor increases choline acetyltransferase but not survival or fiber outgrowth of cultured fetal septal cholinergic neurons. Neuroscience 14:55-68.

Hefti F, Hartikka J, Salvatierra A, Weiner WJ, Mash DC (1986) Localization of nerve growth factor receptors in cholinergic neurons of the human basal forebrain. Neurosci Lett 69:37-41.

Hefti F, Hartikka JA, Montero CN, Junard EO (1988) Role of nerve growth factor in the central nervous system. In: Neurobiology of amino acids, peptides and trophic factors (Ferrendelli JA, ed), pp 127-138. Norwell, MA: Kluwer.

Higgins GA, Koh S, Chen KS, Gage FH (1989) NGF induction of NGF receptor gene expression and cholinergic neuronal hypertrophy within the basal forebrain of the adult rat. Neuron 3:247-256.

Johnson D, Lanahan A, Buck CR, Sehgal A, Morgan C, Mercer E, Bothwell M, Chao M (1986) Expression and structure of the human NGF receptor. Cell 47:545-554.

Johnson EM Jr, Taniuchi M, Clark HB, Springer JE, Koh S, Tayrien MW, Loy R (1987) Demonstration of the retrograde transport of nerve growth factor receptor in the peripheral and central nervous system. J Neurosci 7:923-929.

Johnston MV, Rutkowski JL, Wainer BH, Long JB, Mobley WC (1987) NGF effects on developing forebrain cholinergic neurons are regionally specific. Neurochem Res 12:985-994.

Kitt CA, Mitchell SJ, DeLong MR, Wainer BH, Price DL (1987) Fiber pathways of basal forebrain cholinergic neurons in monkeys. Brain Res 406:192-206.

Klosen P, van den Bosch de Aguilar PH (1987) Neurofilament phosphorylation in degenerating septal neurons. Neuroscience [Suppl] 22: S801.

Köhler C, Chan-Palay V, Wu J-Y (1984) Septal neurons containing glutamic acid decarboxylase immunoreactivity project to the hippocampal region in the rat brain. Anat Embryol 169:41-44.

Koliatsos VE, Martin LJ, Walker LC, Richardson RT, DeLong MR, Price DL (1988) Topographic, non-collateralized basal forebrain projections to amygdala, hippocampus, and anterior cingulate cortex in the rhesus monkey. Brain Res 463:133-139.

Koliatsos VE, Applegate MD, Kitt CA, Walker LC, DeLong MR, Price DL (1989a) Aberrant phosphorylation of neurofilaments accompanies transmitter-related changes in rat septal neurons following transection of the fimbria-fornix. Brain Res 482:205-218.

Koliatsos VE, Mobley WC, Nauta HJW, Price DL (1989b) Responses of central cholinergic neurons to axonal injury in nonhuman primates. Soc Neurosci Abstr 15:408.

Korsching S, Auburger G, Heumann R, Scott J, Thoenen H (1985) Levels of nerve growth factor and its mRNA in the central nervous system of the rat correlate with cholinergic innervation. EMBO J 4: 1389-1393.

Kromer LF (1987) Nerve growth factor treatment after brain injury prevents neuronal death. Science 235:214-216.

Levey AI, Armstrong DM, Atweh SF, Terry RD, Wainer BH (1983) Monoclonal antibodies to choline acetyltransferase: production, specificity, and immunohistochemistry. J Neurosci 3:1-9.

Marano N, Dietzschold B, Earley JJ Jr, Schatteman G, Thompson S, Grob P, Ross AH, Bothwell M, Atkinson BF, Koprowski H (1987) Purification and amino terminal sequencing of human melanoma nerve growth factor receptor. J Neurochem 48:225-232.
Martínez HI, Dreyfus CF, Jonakait GM, Black IB (1987) Nerve growth factor selectively increases cholinergic markers but not neuropeptides in rat basal forebrain in culture. Brain Res 412:295-301.

McLardy T (1955) Observations on the fornix of the monkey. I. Cell studies. J Comp Neurol 103:305-324.

Meier R, Becker-André M, Götz R, Heumann R, Shaw A, Thoenen H (1986) Molecular cloning of bovine and chick nerve growth factor (NGF): delineation of conserved and unconserved domains and their relationship to the biological activity and antigenicity of NGF. EMBO J 5:1489-1493.

Milner TA, Amaral DG (1984) Evidence for a ventral septal projection to the hippocampal formation of the rat. Exp Brain Res 55:579-585.

Milner TA, Loy R, Amaral DG (1983) An anatomical study of the development of the septo-hippocampal projection in the rat. Dev Brain Res 8:343-371.

Mobley WC, Rutkowski JL, Tennekoon GI, Gemski J, Buchanan K, Johnston MV (1986) Nerve growth factor increases choline acetyltransferase activity in developing basal forebrain neurons. Mol Brain Res 1:53-62.

Mobley WC, Neve RL, Prusiner SB, McKinley MP (1988) Nerve growth factor induces gene expression for prion- and Alzheimer's beta-amyloid proteins. Proc Natl Acad Sci USA 85:9811-9815.

Mobley WC, Woo JE, Edwards RH, Riopelle RJ, Longo FM, Weskamp G, Otten U, Valletta JS, Johnston MV (1989) Developmental regulation of nerve growth factor and its receptor in the rat caudateputamen. Neuron 3:655-664.

Montero CN, Hefti F (1988) Rescue of lesioned septal cholinergic neurons by nerve growth factor: specificity and requirement for chronic treatment. J Neurosci 8:2986-2999.

O'Brien TS, Svendsen CN, Isacson O, Sofroniew MV (1990) Loss of true blue labelling from the medial septum following transection of the fimbria-fornix: evidence for the death of cholinergic and noncholinergic neurons. Brain Res 508:249-256.

Pearson RCA, Sofroniew MV, Powell TPS (1984) Hypertrophy of immunohistochemically identified cholinergic neurons of the basal nucleus of Meynert following ablation of the contralateral cortex in the rat. Brain Res 311:194-198.

Perry EK, Gibson PH, Blessed G, Perry RH, Tomlinson BE (1977) Neurotransmitter enzyme abnormalities in senile dementia. J Neurol Sci 34:247-265.

Perry RH, Candy JM, Perry EK, Irving D, Blessed G, Fairbairn AF, Tomlinson BE (1982) Extensive loss of choline acetyltransferase activity is not reflected by neuronal loss in the nucleus of Meynert in Alzheimer's disease. Neurosci Lett 33:311-315.

Phelps CH, Gage FH, Growdon JH, Hefti F, Harbaugh R, Johnston MV, Khachaturian Z, Mobley W, Price D, Raskind M, Simpkins J, Thal L, Woodcock J (1989a) (Ad hoc working group on nerve growth factor and Alzheimer's disease) Potential use of nerve growth factor to treat Alzheimer's disease. Science 243:11.

Phelps CH, Gage FH, Growdon JH, Hefti F, Harbaugh R, Johnston MV, Khachaturian ZS, Mobley WC, Price DL, Raskind M, Simpkins J, Thal LJ, Woodcock J (1989b) Potential use of nerve growth factor to treat Alzheimer's disease. Neurobiol Aging 10:205-207.

Poletti CE, Creswell G (1977) Fornix system efferent projections in the squirrel monkey: an experimental degeneration study. J Comp Neurol 175:101-128.

Presty SK, Bachevalier I, Walker LC, Struble RG, Price DL, Mishkin M, Cork LC (1987) Age differences in recognition memory of the rhesus monkey (Macaca mulatta). Neurobiol Aging 8:435-440.

Price DL (1986) New perspectives on Alzheimer's disease. Annu Rev Neurosci 9:489-512.

Rosenberg MB, Friedmann T, Robertson RC, Tuszynski M, Wolff JA, Breakefield XO, Gage FH (1988) Grafting genetically modified cells to the damaged brain: restorative effects of NGF expression. Science 242:1575-1581.

Rosene DL, Van Hoesen GW (1977) Hippocampal efferents reach widespread areas of cerebral cortex and amygdala in the rhesus monkey. Science 198:315-317.

Rosene DL, Van Hoesen GW (1987) The hippocampal formation of the primate brain. A review of some comparative aspects of cytoarchitecture and connections. In: Cerebral cortex (Jones EG, Peters A, eds), Vol 6, pp 345-456. New York: Plenum.

Schatteman GC, Gibbs L, Lanahan AA, Claude P, Bothwell M (1988) Expression of NGF receptor in the developing and adult primate central nervous system. J Neurosci 8:860-873. 
Seiler M, Schwab ME (1984) Specific retrograde transport of nerve growth factor (NGF) from neocortex to nucleus basalis in the rat. Brain Res 300:33-39.

Shelton DL, Reichardt LF (1986) Studies on the expression of the $\beta$ nerve growth factor (NGF) gene in the central nervous system: level and regional distribution of NGF mRNA suggest that NGF functions as a trophic factor for several distinct populations of neurons. Proc Natl Acad Sci USA 83:2714-2718.

Sofroniew MV, Pearson RCA, Eckenstein F, Cuello AC, Powell TPS (1983) Retrograde changes in cholinergic neurons in the basal forebrain of the rat following cortical damage. Brain Res 289:370-374.

Sofroniew MV, Pearson RCA, Powell TPS (1987) The cholinergic nuclei of the basal forebrain of the rat: normal structure, development and experimentally induced degeneration. Brain Res 411:310-331.

Stach RW, Perez-Polo JR (1987) Binding of nerve growth factor to its receptor. J Neurosci Res 17:1-10.

Swanson LW (1976) An autoradiographic study of the efferent connections of the preoptic region in the rat. J Comp Neurol 167:227256.

Swanson LW, Cowan WM (1979) The connections of the septal region in the rat. J Comp Neurol 186:621-655.

Swanson LW, Köhler C, Björklund A (1987) The limbic region. I: the septohippocampal system. In: Integrated systems of the CNS, Part I, Handbook of chemical neuroanatomy (Björklund A, Hökfelt T, Swanson LW, eds), Vol 5, pp 125-277. Amsterdam: Elsevier.

Szabo J, Cowan WM (1984) A stereotaxic atlas of the brain of the cynomolgus monkey (Macaca fascicularis). J Comp Neurol 222:256300.

Taniuchi M, Schweitzer JB, Johnson EM Jr (1986) Nerve growth factor receptor molecules in rat brain. Proc Natl Acad Sci USA 83:19501954.

Thoenen H, Barde Y-A, Davies AM, Johnson JE (1987) Neurotrophic factors and neuronal death. Ciba Found Symp 126:82-95.
Tsuji S (1974) On the chemical basis of thiocholine methods for demonstration of acetylcholinesterase activities. Histochemistry 42:99110.

Tuszynski MH, Armstrong DM, Gage FH (1990) Basal forebrain cell loss following fimbria/fornix transection. Brain Res 508:241-248.

Walker LC, Price DL, Young WS III (1989) GABAergic neurons in the primate basal forebrain magnocellular complex. Brain Res 499: 188-192.

Weskamp G, Otten U (1987) An enzyme-linked immunoassay for nerve growth factor (NGF): a tool for studying regulatory mechanisms involved in NGF production in brain and in peripheral tissues. $J$ Neurochem 48:1779-1786.

Whitehouse PJ, Price DL, Struble RG, Clark AW, Coyle JT, DeLong MR (1982) Alzheimer's disease and senile dementia: loss of neurons in the basal forebrain. Science 215:1237-1239.

Whittemore SR, Seiger $\AA$ (1987) The expression, localization and functional significance of $\beta$-nerve growth factor in the central nervous system. Brain Res Rev 12:439-464.

Whittemore SR, Holets VR, Levy DJ (1989) Transplantation of a hippocampal, NGF-secreting, temperature-sensitive cell line into adult rats with fimbria-fornix lesions spares cholinergic septal neurons. Mol Neurobiol Neuropharmacol 9:85.

Will B, Hefti F (1985) Behavioural and neurochemical effects of chronic intraventricular injections of nerve growth factor in adult rats with fimbria lesions. Behav Brain Res 17:17-24.

Williams LR, Varon S, Peterson GM, Wictorin K, Fischer W, Björklund $\hat{A}$, Gage FH (1986) Continuous infusion of nerve growth factor prevents basal forebrain neuronal death after fimbria fornix transection. Proc Natl Acad Sci USA 83:9231-9235.

Wyss JM, Swanson LW, Cowan WM (1980) The organization of the fimbria, dorsal fornix and ventral hippocampal commissure in the rat. Anat Embryol 158:303-316. 